\title{
Temporal and Spatial Variation on Heavy Metal Concentrations in the bivalve Perna perna (LINNAEUS, 1758) on the Northern Coast of Rio de Janeiro State, Brazil
}

\author{
Alexandre Gomes Ferreira*, André Luís dos Santos Machado and Ilana Rosental Zalmon \\ Universidade Estadual do Norte Fluminense; Centro de Biociências e Biotecnologia; Laboratório de Ciências \\ Ambientais; alexandre@uenf.br; Av. Alberto Lamego, 2000; Horto; 28015-620; Campos dos Goytacazes - RJ - \\ Brazil
}

\begin{abstract}
Heavy metal ( $\mathrm{Cd}, \mathrm{Cr}, \mathrm{Cu}, \mathrm{Fe}, \mathrm{Mn}, \mathrm{Ni}, \mathrm{Pb}$ and $\mathrm{Zn}$ ) concentrations were studied in Perna perna from three beaches (Barra do Furado, Buena and Ponta do Retiro) on the northern coast of Rio de Janeiro State by ICP-AES. The average concentration was $0.3 \pm 0.04(\mathrm{Cd}) ; 1.9 \pm 0.6(\mathrm{Cr}) ; 6.1 \pm 0.7(\mathrm{Cu}) ; 1,130 \pm 113(\mathrm{Fe}) ; 22 \pm 3.2(\mathrm{Mn}) ; 9.3 \pm$ $4.6(\mathrm{Ni}) ; 0.4 \pm 0.2(\mathrm{~Pb}) ; 44 \pm 5.8(\mathrm{Zn}) \mu \mathrm{g} . \mathrm{g}^{-1}$ dry weight. There were no significant difference for almost all the studied metals in relation to sex. Although, significant spatial variations $(p<0.05)$ occurred for $\mathrm{Cr}, \mathrm{Pb}$ and $\mathrm{Ni}$ with higher values for Barra do Furado. Temporal variations were significant $(p<0.05)$ at the three beaches, however, no trends of accumulation were observed. The metal concentrations were similar to areas under low pollution impact, except for Fe, which was probably due to the local substrates enriched in iron oxides.
\end{abstract}

Key words: Heavy metals, mollusk, spatial variation and temporal variation

\section{INTRODUCTION}

Coastal waters are commonly situated as an endpoint of toxic and environmentally harmful chemicals by direct and indirect inputs (Moraes and Silva, 1995; Nybakken, 1997). Trace elements are natural components of the hydrosphere, although anthropogenic activities had already altered its geochemical cycles increasing people's attention. Since marine organisms accumulate and concentrate heavy metals in high levels, they are widely used as biomonitor organisms reflecting the extent of metal pollution in the coastal waters (Lacerda et al. 1985, Szefer et al. 1998). One of the most successful efforts is popularly known as the Mussel Watch Program (Cantillo, 1998).
Heavy metal toxicity to aquatic organisms in association with the capacity to entry and to keep on the trofic chain for long time justifies metal determination studies on aquatic organisms. However, it's hard to work with environmental contamination by heavy metals due the complex biogeochemistry of these elements on aquatic environments (Förstner and Witmann, 1983). Thus, it is necessary to monitor and to preserve the aquatic environments against the anthropogenic pollution by heavy metals through the knowledge of the base levels of these trace elements.

The aim of this work is to determine $\mathrm{Cd}, \mathrm{Cr}, \mathrm{Cu}$, $\mathrm{Fe}, \mathrm{Mn}, \mathrm{Ni}, \mathrm{Pb}$ and $\mathrm{Zn}$ concentrations in the bivalve Perna perna (LINNAEUS, 1758) collected on the northern coast of Rio de Janeiro

\footnotetext{
* Author for correspondence
} 
State at three beaches: Barra do Furado (BF) $\left(22^{\circ}\right.$ $\left.\mathrm{S} ; 41^{\circ} \mathrm{W}\right)$, Buena (B) $\left(21^{\circ} 29^{\prime} \mathrm{S} ; 41^{\circ} \mathrm{W}\right)$ and Ponta

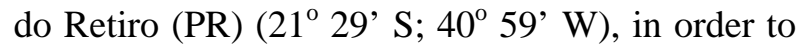
evaluate the temporal and the spatial variation of these metals concentrations and to identify the critical elements in each sampled area.

The following hypotheses were tested: i) there is no difference in $P$. perna metal concentrations in relation to sex; ii) heavy metal concentrations are different among the sampled areas in accordance with local characteristics (different substrate, surface runoff, running coastal waters); iii) there is a seasonal variation on metal concentration along the year.

\section{MATERIAL AND METHODS}

Mussels with similar length $(4.0,5.0 \mathrm{~cm})$ were collected on the low-middle littoral at three beaches every 45 days approximately (from July/98 to May/99). The samples were washed with local seawater, and transported in plastic bags to the laboratory. In the lab, the soft tissues were removed from their shells and the sex was determinate.

The samples were grouped $(\mathrm{n}=15)$ according to their sex, oven-dried at $60{ }^{\circ} \mathrm{C}$, ground to a fine powder with a porcelain pestle and mortar. Aliquots (approximately $1.00 \mathrm{~g}$ of dried tissue) were digested (triplicate) in concentrate $\mathrm{HNO}_{3}$, evaporated and redissolved in $0.5 \mathrm{~N} \mathrm{HNO}_{3}$ (PáezOsuna et al., 1995; Riget et al., 1997). The extracts were analyzed by atomic emission spectrophotometry with induced coupled plasma (ICP-AES).

Standard reference material was analyzed in order to estimate the accuracy of the digestion method (Muscular Tissue of Squalus acanthias, DORM 1) supplied by the Marine Analytical Chemistry Standards Programs (Canada). The heavy metals recovery rates were $84(\mathrm{Cr}), 102(\mathrm{Cu}), 99(\mathrm{Fe}), 87$ (Mn), $93(\mathrm{Ni})$ e $88(\mathrm{Zn}) \%$.

The Mann-Whitney statistical analyze $(\mathrm{p}<0.05)$ were applied in order to compare the metal concentrations between the sampled areas and sex. The Kruskal-Wallis $(\mathrm{p}<0.05)$ variance test were applied to compare the temporal variation of the metal concentration in each sampled area.

\section{RESULTS AND DISCUSSION}

In general, $\mathrm{Cd}, \mathrm{Cu}, \mathrm{Mn}, \mathrm{Ni}, \mathrm{Pb}$ and $\mathrm{Zn}$ concentrations in P. perna at Ponta do Retiro, Buena and Barra do Furado beaches could be considered as natural background levels (Table 1). These results reflected the usual fluctuations of these metals and their availability for the biota incorporation on the northern coast of Rio de Janeiro State. Similar variability were observed at the same beaches by Rezende et al. (1997) and by Machado (1999) for $\mathrm{Cr}, \mathrm{Cu}, \mathrm{Fe}, \mathrm{Mn}$ and $\mathrm{Zn}$ concentrations in two macroalgae species.

Comparing the present work with the data base of the International Mussel Watch Program (Table 1) (Cantillo, 1998), our results showed similar average concentrations for $\mathrm{Cr}\left(1.9 v s 1.6 \mu \mathrm{g} . \mathrm{g}^{-1}\right.$ d.w.) and $\mathrm{Cu}\left(6.1\right.$ vs $7.9 \mu \mathrm{g} . \mathrm{g}^{-1}$ d.w.), higher for $\mathrm{Ni}$ (9.3 vs 2.2) and lower for Cd $\left(0.3 v s 2.0 \mu \mathrm{g}^{-\mathrm{g}^{-1}}\right.$ d.w.), $\mathrm{Pb}\left(0.3\right.$ vs $5.0 \mu \mathrm{g} . \mathrm{g}^{-1}$ d.w.) and $\mathrm{Zn}(44$ vs 130 $\mu \mathrm{g} . \mathrm{g}^{-1}$ d.w.). High concentrations for $\mathrm{Cd}$ and $\mathrm{Pb}$ at the Mussel Watch data came from programs specifically designed to sample "hot spots".

Specifically for $\mathrm{Fe}$, the results showed concentration values close to the areas described under high impact pollution (Table 1), with average values equal or superior to $1000 \mu \mathrm{g}$.g- 1 of dry weight (d.w.) at three beaches. These results could be related to the presence of this element on the local substrate which has been rich in iron oxides (Pedrini, 1984). This hypothesis was confirmed by Rezende and Lacerda (1986) who studied the capacity of $\mathrm{P}$. perna to accumulate Fe in accordance with the colonized substrate type. The high capacity for Mytillidae to accumulate $\mathrm{Fe}$ were described by Regoli and Orlando (1994). They observed a rapid and an elevated $\mathrm{Fe}$ absorption as precipitated hydroxides within endocitycs vesicles and in the intertubular spaces. The average of $\mathrm{Cu}\left(6.13 \pm 0.5 \mu \mathrm{g} . \mathrm{g}^{-1}\right.$ d.w. or $0.9 \pm$ $0.1 \mu \mathrm{g} . \mathrm{g}^{-1}$ w.w. $)$ and $\mathrm{Zn}\left(45 \pm 6.8 \mu \mathrm{g} . \mathrm{g}^{-1}\right.$ d.w. or $6.3 \pm 0.8 \mu \mathrm{g} . \mathrm{g}^{-1}$ w.w.) concentrations were close to the values described for areas with low pollution impact (Carvalho et al., 1993; Szefer et al., 1998) and lower than the maximum concentration for human consumption established by Brazilian Federal Legislation (1978) (Table 1). 
Table 1 - Average concentrations of $\mathrm{Cd}, \mathrm{Cr}, \mathrm{Cu}, \mathrm{Fe}, \mathrm{Mn}, \mathrm{Ni}, \mathrm{Pb}$ e $\mathrm{Zn}\left(\mu \mathrm{g} \cdot \mathrm{g}^{-1}\right.$ dry weight) in mollusks of nonimpacted (a) and impacted (b) areas for heavy metals $\mathrm{MC}=$ Maximum Concentration for human consumption in $\underline{\mu \mathrm{g} . \mathrm{g}^{-1} \text { of wet weight (w.w.). }}$

\begin{tabular}{|c|c|c|c|c|c|c|c|}
\hline Sample area/Specie & $\mathbf{N}$ & Pollut. & Cd & $\mathrm{Cr}$ & $\mathbf{C u}$ & $\mathbf{F e}$ & Reference \\
\hline B. Guanabara/P. perna & - & (b) & - & - & 14.5 & 171.5 & Rezende and Lacerda, 1986 \\
\hline Yemen/P. perna & - & (b) & 0.6 & - & 27 & 900 & Szefer et al., 1997 \\
\hline México/M. strigata & - & (a) & 0.63 & 0.7 & 23 & 190 & Szefer et al., 1998 \\
\hline Japão/M. edulis & - & (b) & 3.2 & 5.1 & - & 314 & Szefer et al., 1997 \\
\hline B. Sepetiba/P. perna & - & (b) & 1.0 & - & 6.5 & - & Carvalho et al., 1993 \\
\hline A. dos Reis/P. perna & - & (a) & 1.0 & - & 8.9 & - & Carvalho et al., 1993 \\
\hline Macaé/P. perna & - & (a) & 0.3 & 1.3 & 5.1 & 675 & Carvalho et al., 1998 \\
\hline El Salvador/O. iridescens & - & (b) & $<1.2$ & 15.8 & 622 & - & Michel and Zengel, 1998 \\
\hline B. Sepetiba/C. brasiliana & - & (b) & 8.5 & - & 24.5 & - & Gomes et al., 1991 \\
\hline A. dos Reis/C. brasiliana & - & (a) & 1.7 & - & 227 & - & Gomes et al., 1991 \\
\hline ** World Mussel Watch & - & - & 2.0 & 1.6 & 7.9 & - & Cantillo, 1998 \\
\hline P. Retiro/P. perna & 30 & - & $\begin{array}{l}0.3 / \\
0.04\end{array}$ & $\begin{array}{l}1.7 / \\
0.24\end{array}$ & $\begin{array}{l}6.0 / \\
0.86\end{array}$ & $\begin{array}{c}1190 / \\
170\end{array}$ & * Present work, 1999 \\
\hline Buena/P. perna & 30 & - & $\begin{array}{l}0.3 / \\
0.04\end{array}$ & $\begin{array}{l}1.4 / \\
0.20\end{array}$ & $\begin{array}{l}6.7 / \\
0.96\end{array}$ & $\begin{array}{c}1000 / \\
143\end{array}$ & * Present work, 1999 \\
\hline B. Furado/P. perna & 30 & - & $\begin{array}{c}0.3 \\
/ 0.04\end{array}$ & $\begin{array}{l}2.5 / \\
0.36\end{array}$ & $\begin{array}{l}5.7 / \\
0.81\end{array}$ & $\begin{array}{c}1200 / \\
171\end{array}$ & * Present work, 1999 \\
\hline MC (w.w.) & - & - & 1 & 0.1 & 30 & - & $\begin{array}{c}\text { Brazilian Federal Legislation, } \\
1978\end{array}$ \\
\hline
\end{tabular}

\begin{tabular}{cccc|c|c|c|c|c}
\hline Sample area/Specie & N & Pollut. & Mn & Ni & Pb & Zn & Reference \\
\hline B. Guanabara/P. perna & - & (b) & 20 & 19 & 20.9 & 565.5 & Rezende and Lacerda, 1986 \\
Yemen/P. perna & - & (b) & 60 & - & 5.2 & 40 & Szefer et al., 1997 \\
México/M. strigata & - & (a) & 24 & 16 & 0.8 & 42 & Szefer et al., 1998 \\
Japão/M. edulis & - & (b) & - & - & - & 1773 & Szefer et al., 1997 \\
B. Sepetiba/P. perna & - & (b) & 18.4 & 7.4 & $<1.3$ & 205.3 & Carvalho et al., 1993 \\
A. dos Reis/P. perna & - & (a) & 35.7 & 9.8 & 2 & 153 & Carvalho et al., 1993 \\
Macaé/P. perna & - & (a) & 9.3 & 8.6 & 1.8 & 79 & Carvalho et al., 1998 \\
El Salvador/O. iridescens & - & (b) & - & 10.6 & $<1.2$ & 2040 & Michel and Zengel, 1998 \\
B. Sepetiba/C. brasiliana & - & (b) & 30.1 & 18.1 & 13.5 & 9500 & Gomes et al., 1991 \\
A. dos Reis/C. brasiliana & - & (a) & 30.5 & 25 & $<1.3$ & 2349 & Gomes et al., 1991 \\
** World Mussel Watch & - & - & - & 2.2 & 5.0 & 130 & Cantillo, 1998 \\
P. Retiro/P. perna & 30 & - & $26 /$ & $12 /$ & $0.4 /$ & $40 /$ & * Present work, 1999 \\
& & & 3.71 & 1.71 & 0.06 & 5.71 & * Present work, 1999 \\
Buena/P. perna & 30 & - & $20 /$ & $4 / 0.60$ & $0.1 /$ & $42 /$ & * \\
& & & 2.86 & & 0.01 & 6.00 & Present work, 1999 \\
B. Furado/P. perna & 30 & - & $21 /$ & $12 /$ & $0.5 /$ & $51 /$ & Brazilian Federal Legislation, \\
& & & 3.00 & 1.71 & 0.07 & 7.29 & 1978 \\
\hline MC (w.w.) & - & - & - & - & 20 & 50 &
\end{tabular}

\footnotetext{
* The present work concentrations are expressed in $\mu \mathrm{g} . \mathrm{g}^{-1}$ of dry weight and in $\mu \mathrm{g} . \mathrm{g}^{-1}$ of wet weight $\left(\mu \mathrm{g} . \mathrm{g}^{-1}\right.$ d.w../ $\mu \mathrm{g} . \mathrm{g}^{-1}$ w.w.) ** World Mussel Watch data base, median concentration.
}

Moreover, comparing with oyster results described by Gomes et al. (1991) and Michel and Zengel (1998), the $\mathrm{Cu}$ and $\mathrm{Zn}$ concentrations in P. perna were especially lower. This trend was observed by Chapman et al. (1996) evidencing the high oyster capacity to accumulate this metals comparing with Mytilidae family members.
The $\mathrm{Cr}$ concentrations in $P$. perna $(1.89 \pm 0.6$ $\mu \mathrm{g} . \mathrm{g}^{-1}$ d.w. or $0.3 \pm 0.1 \mu \mathrm{g} . \mathrm{g}^{-1}$ w.w.) were higher than the maximum consumption limit established by the Brazilian Legislation (1978) (Table 1). However, Lima (1997) studying the Cr distribution in different areas on the Rio de Janeiro coast observed that the maximum concentration 
permissible for human consumption have been overpassed, even in natural waters. Similar results were observed by Carvalho et al. (1998) studying the metal concentrations in $P$. perna at Macaé coast, close to the present studied area. Our results, in accordance with these authors might be indicating the natural capacity of $P$. perna to concentrate elevated amounts of this metal in the environment.

Cd $\left(0.3 \pm 0.03 \mu \mathrm{g} . \mathrm{g}^{-1}\right.$ d.w. $), \operatorname{Mn}\left(23 \pm 3.1 \mu \mathrm{g} . \mathrm{g}^{-1}\right.$ d.w.), $\mathrm{Ni}\left(8 \pm 4.8 \mu \mathrm{g} . \mathrm{g}^{-1}\right.$ d.w. $)$ and $\mathrm{Pb}(0.4 \pm 0.2$ $\mu \mathrm{g} . \mathrm{g}^{-1}$ d.w.) presented concentrations near to low pollution impact areas for heavy metals as described by the literature (Table 1 ).

Nevertheless, comparing the Mn results with those of Carvalho et al. (1998) working near Barra do Furado beach $\left(9.3 \mu \mathrm{g} . \mathrm{g}^{-1}\right.$ d.w. $)$ high concentrations were observed in the present study. The same condition was observed for Fe. These findings showed different sources of this two metals in the northern coast of Rio de Janeiro State and it could be related to a singular terrestrial input in association with suspension particulate matter.

\section{Metal concentrations and Sex}

Many authors have highlighted the importance of sex concerning the variation on metal concentrations during the reproductive season. During this stage, proteins and carbohydrates contents, which have high affinity for heavy metals, are very recruited for gonad tissue production, energetic storage and consumption (Latouxe and Mix, 1982; Páez-Osuna et al. 1995; Lima, 1997).

The results showed no significant differences for $\mathrm{Cr}, \mathrm{Cu}, \mathrm{Fe}, \mathrm{Mn}, \mathrm{Pb}$ and $\mathrm{Zn}$ concentrations between $P$. perna male and female. This could be associated to restricted and short length of these organisms $(4.0,5.0 \mathrm{~cm})$, in accordance with Rezende and Lacerda (1986). The authors did not find differences on heavy metal concentration between males and females of Mytillidae within the same class length $(5.5,6.0 \mathrm{~cm})$. However, Lima (1997) showed significant differences ( $p<$ 0.05 ) on $\mathrm{Cd}, \mathrm{Cu}$, and $\mathrm{Zn}$ values among males and females of P. perna on Rio de Janeiro State coast with the highest one on males. Latouche and Mix (1982) reported that the gonadal stage could influence the heavy metal bioconcentration in bivalve mollusks. Coimbra and Carraça (1990) suggested the use of immature bivalves in environmental monitoring programs for heavy metals since the youngest mollusks showed reduced gonadal growth.

Significant differences $(\mathrm{p}<0.05)$ for $\mathrm{Cd}$ and $\mathrm{Ni}$ among males and females of $P$. perna occurred in Buena beach with highest values always for females. These results suggested the need of additional studies in order to evaluate the natural fluctuations of this metals between both sexes at these site.

\section{Spatial variation for heavy metal concentrations in Perna perna}

No significant differences for $\mathrm{Cd}, \mathrm{Cu}, \mathrm{Fe}, \mathrm{Mn}$ and $\mathrm{Zn}$ among the three studied areas were observed (Fig. 1). These results might be associated to a similar bioavailability of these metals to $P$. perna. Besides, all these elements (Cd in exception) are essential metals, which probably have intracellular regulatory mechanisms to keep their concentrations in equilibrium in the organism.

There were significant differences $(\mathrm{p}<0.05)$ on $\mathrm{Cr}$ concentrations between Barra do Furado and the other beaches (Fig. 1). The highest values observed at the first could be related to a high availability of this metal in the area. Similar results at the same area were described by Machado (1999) for marine benthic algae. The author suggests that the dissolved fraction could be the major metal incorporation way for marine macroalgae and an additional source for $\mathrm{Cr}$ incorporation by mollusks.

Significant differences $(\mathrm{p}<0.05)$ in $\mathrm{Pb}$ concentrations among Barra do Furado and the other beaches were observed (Fig. 1) with higher values at the former, although the concentrations were lower than the described for non-impacted areas (Phillips et al., 1982; Riget et al., 1997). The highest $\mathrm{Pb}$ concentrations observed at Barra do Furado could be associated with the presence of a shipyard neared the sampled area. Chiu et al. (2000) suggested that an increasing in shipping could lead to increase in $\mathrm{Pb}$ bioavailability for mariculture zones on coastal waters. 

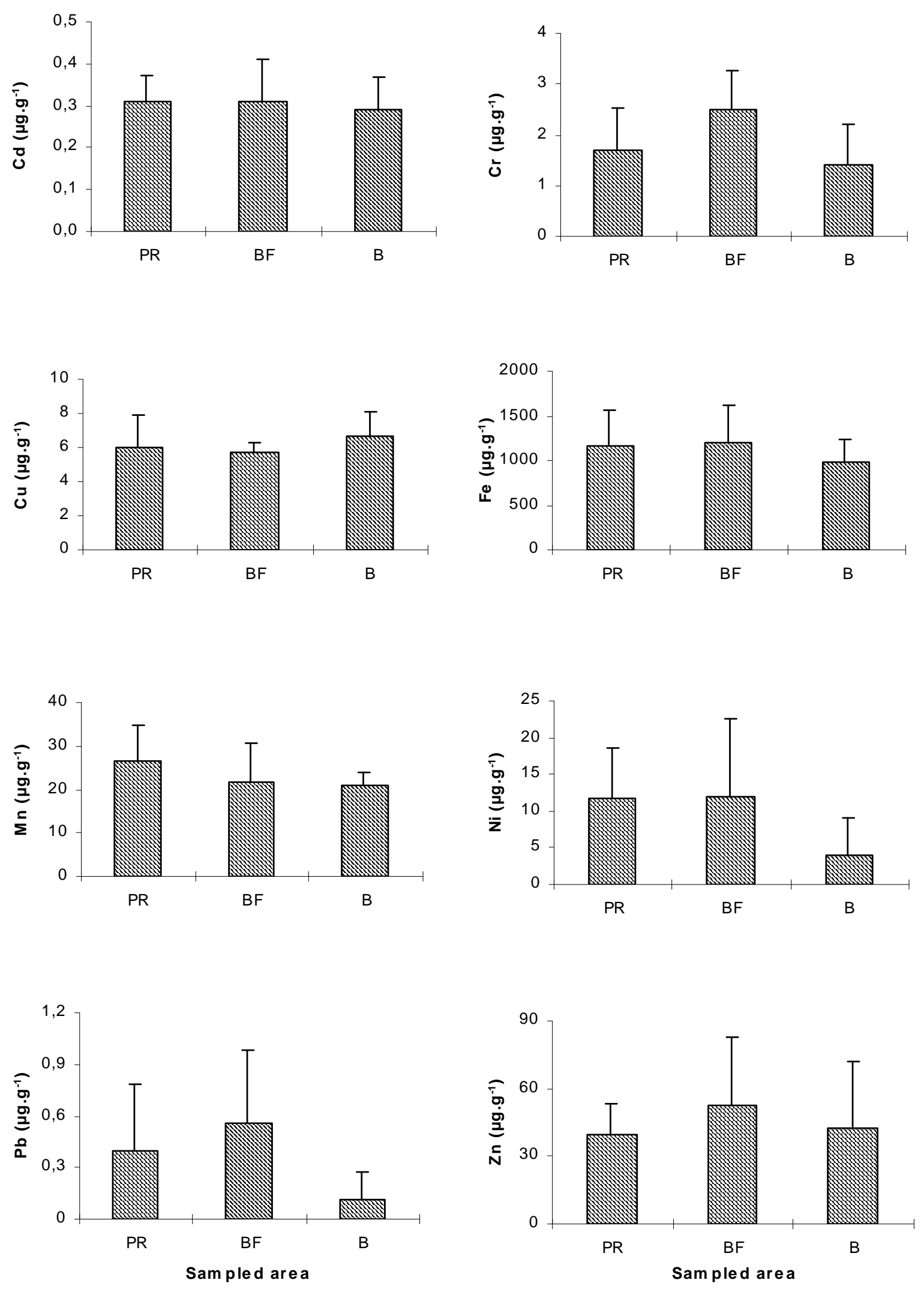

Figure 1 - Average and standard deviation of $\mathrm{Cd}, \mathrm{Cr}, \mathrm{Cu}, \mathrm{Fe}, \mathrm{Mn}, \mathrm{Ni}, \mathrm{Pb}$ and $\mathrm{Zn}$ concentrations $\mu \mathrm{g} . \mathrm{g}^{-1}$ (dry weight $)$ in each sampled area $(\mathrm{PR}=$ Ponta do Retiro; $\mathrm{BR}=$ Barra do Furado; $\mathrm{B}=$ Buena $)(\mathrm{N}=30)$. 

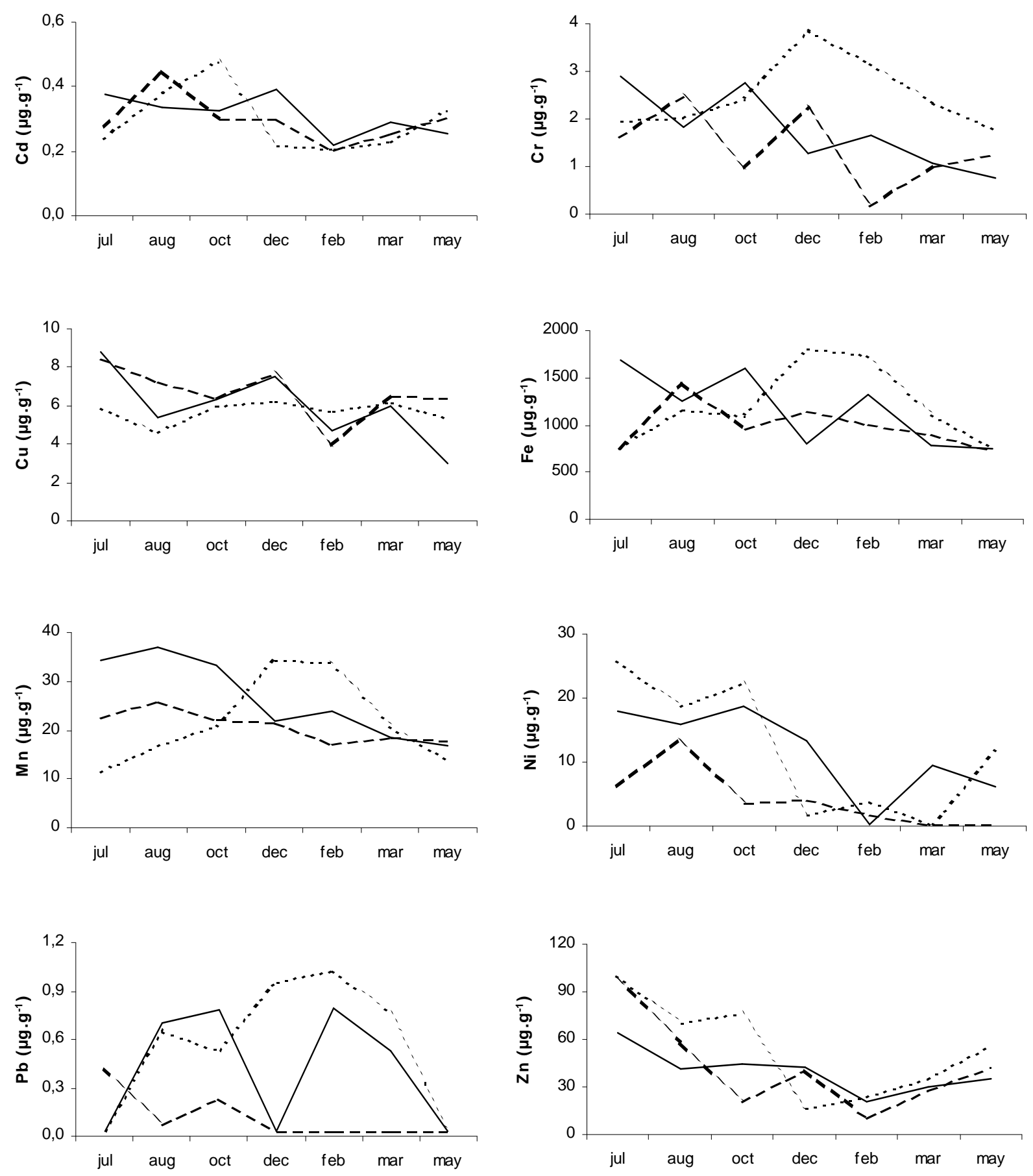

Retiro

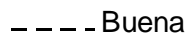

B. Furado

Figure 2 - Temporal variation of $\mathrm{Cd}, \mathrm{Cr}, \mathrm{Cu}, \mathrm{Fe}, \mathrm{Mn}, \mathrm{Ni}, \mathrm{Pb}$ and $\mathrm{Zn}$ concentrations $\mu \mathrm{g} . \mathrm{g}^{-1}$ (average in dry weight) in each sampled area (Ponta do Retiro; Barra do Furado; Buena). 


\section{Temporal variation for heavy metal concentration in Perna perna}

\section{Barra do Furado}

Significative temporal variations $(p<0.05)$ were registered in Barra do Furado (Fig. 2) for all the metallic elements, except for $\mathrm{Cu}$, an important and essential microelement acting as a respiratory pigment of marine invertebrates and which could be metabolically regulated by mollusks (Förstner and Wittmann, 1983). Similar findings were observed by Wong et al. (2000) studying the heavy metal concentrations in Perna viridis from Hong Kong.

$\mathrm{Cr}, \mathrm{Fe}, \mathrm{Mn}, \mathrm{Pb}$ and $\mathrm{Zn}$ concentrations presented higher concentrations on December/98 and February/99. This behavior is probably indicating that these elements, that are reaching the coastal environment, are from the same source, and follow a similar distribution pattern. C.I.D.E. (1997) explained that the north of Rio de Janeiro State have humid floodplain areas enriched with organic and vegetable material in different degradation stages with concomitant heavy metal liberation, mainly Fe and Mn (Salomão, 1997). During the rainy season (December, March), this inundated areas might be releasing these metallic elements linked to the suspended particulate matter (Kremiling, 1988) by superficial runoff until the local rivers and lakes, as the Flechas creek, an important communication way between the continental inundate areas and the coastal environment of Barra do Furado. Consequently these compounds would be ready for the marine organisms uptake.

\section{Ponta do Retiro}

Significant temporal variations $(\mathrm{p}<0.05)$ occurred for all metals in Ponta do Retiro (Fig. 2). Cr, $\mathrm{Cu}$, $\mathrm{Fe}, \mathrm{Mn}$ and $\mathrm{Zn}$ concentrations were higher during July/98 and October/98, possibly due to a common origin for these metals. At the same time lower rain levels were registered (average of $34.2 \mathrm{~mm}$ ) comparing with December/98 to May/99 (average of $77.1 \mathrm{~mm}$ ). These results indicated that the rainy season in Ponta do Retiro beach, in contrast with Barra do Furado, was not related to an elevation of heavy metal bioavailability to P. perna. However, in accordance to Kavun et al. (2002), an increasing filtration rate could be produced in response to regionally low levels of chlorophyll-a, seston and suspended matter which probably influence the metal accumulation in $P$. perna.

The $\mathrm{Cd}$, $\mathrm{Ni}$ and $\mathrm{Pb}$ elements didn't show high concentration peaks during the same months in Ponta do Retiro. This high variability could be indicating that the bioavailability and the dynamic of these elements have a complex regulation level that makes difficult an identification of the origin of these elements, mainly if we considered the reduced natural abundance of these metals.

\section{Buena}

Overall, there weren't significative temporal variation in $\mathrm{Mn}$ and $\mathrm{Cu}$ concentrations in Buena beach (Fig. 2), suggesting a good metabolic regulation of these metallic elements for $P$. perna.

$\mathrm{Cd}, \mathrm{Cr}, \mathrm{Fe}, \mathrm{Ni}, \mathrm{Pb}$ and $\mathrm{Zn}$ showed a tendency to accumulate during July and August/98. These results, as in Ponta do Retiro, were supposed to be related to an elevated filtration rate, which was generally accompanied by a rise in the assimilation of heavy metals from food sources. Fe showed significant temporal variation, with different incorporation periods. These results might reflect the singular capacity of $P$. perna to concentrate and to regulate this metallic element. It did not show a similar behavior at the three beaches, although the close proximity of Buena and Ponta do Retiro beaches (12 Km approximately).

Variations on metal concentrations in mussels during the year ware possibly influenced by several factors (i.e. metal bioavailability, season and the physiology of the mussels (Lacerda et al. 1983; Wong et al. 2000). Suspended particulate matter, a heavy metal source for marine environment (Pfeiffer, 1980; Páez-Osuna et al. 1995; De Gregori et al. 1996) could also provide valuable information to understanding the metal dynamic on the northern coast of Rio de Janeiro State, especially if we considered the local influence of fluvial inputs and the distinct pluviometric fate between the sampled areas.

Finally, we recommend the use of younger specimens of Perna perna to monitor the heavy metal concentrations, particularly $\mathrm{Cr}$ and $\mathrm{Fe}$, in Ponta do Retiro, Buena and Barra do Furado beaches since this organism showed high capacity to accumulate these metals: satisfactory length, wide distribution and great abundance. 


\section{AKNOWLEDGEMENTS}

The authors thank Dr. Carlos Eduardo Veiga de Carvalho for suggestions and comments during the manuscript revision. This work has been supported by Conselho Nacional de Desenvolvimento Científico e Tecnológico (CNPq) and Fundação Estadual do Norte Fluminense (FENORTE).

\section{RESUMO}

Este trabalho descreve as concentrações de $\mathrm{Cd}, \mathrm{Cr}$, $\mathrm{Cu}, \mathrm{Fe}, \mathrm{Mn}, \mathrm{Ni}, \mathrm{Pb}$ and $\mathrm{Zn}$ em Perna perna das praias de Barra do Furado (BF), Buena (B) and Ponta do Retiro (PR) na costa Norte do Estado do Rio de Janeiro. As concentrações dos metais foram determinadas em ICP-AES. As concentrações médias foram $0.3 \pm 0.04(\mathrm{Cd}) ; 1,9 \pm 0.6(\mathrm{Cr}) ; 6,13$ $\pm 0.7(\mathrm{Cu}) ; 1.130 \pm 113(\mathrm{Fe}) ; 22 \pm 3,2(\mathrm{Mn}) ; 9.3 \pm$ $4,6(\mathrm{Ni}) ; 0.4 \pm 0.2(\mathrm{~Pb}) ; 44 \pm 5,8(\mathrm{Zn}) \quad \mu \mathrm{g} . \mathrm{g}^{-1} \mathrm{de}$ peso seco. Não ocorreram diferenças significativas para a maioria dos metais, em relação ao sexo. Variações espaciais significativas $(\mathrm{p}<0.05)$ ocorreram para $\mathrm{Cr}, \mathrm{Pb}$ e $\mathrm{Ni}$ com os maiores valores em BF. Variações temporais significativas $(\mathrm{p}<0.05)$ ocorreram nas três praias, contudo, nenhuma tendência sazonal de acumulação foi observada. As concentrações dos metais foram similares aquelas áreas descritas sob baixo impacto de poluição por metais pesados, exceto para o $\mathrm{Fe}$, cujos altos valores provavelmente estão associados a presença de substratos locais ricos em óxido de Fe.

\section{REFERENCES}

Cantillo, A. Y. (1998), Comparison of Results of Mussel Watch Programs of the United States and France With Worldwide Mussel Watch Studies. Mar. Pollut. Bullet., 36 : (9), 712-717 pp.

Carvalho, C. E. V.; Lacerda. L. D. and Gomes, M. P. (1993), Metais pesados na biota bêntica da Baía de Sepetiba e Angra dos Reis, RJ. Acta Limno. Brasil., 6, 222-229.

Carvalho, C. E. V.; Cavalcante, M. P. O.; Gomes, M. P.; Faria, V. V. and Rezende, C. E. (1998), Distribuição de metais pesados em mexilhões $P$. perna da Ilha de Santana (Macaé, RJ). . Anais. 5. Enc. Brasil. Ecotox., Itajaí, SC. 44 pp.
Carvalho, C. E. V.; Ovalle, A. R. C.; Rezende, C. E.; Molisani, M. M.; Salomão, M. S. M. B. and Lacerda, L. D. (1998), Seazonal Variation of Particulate Heavy Metals in the Lower Paraíba do Sul River, RJ, Brazil. Environm. Geol. Cases and Solutions, 621, 1-8 pp.

Chapman, P. M.; Allen, H.; Godtfredsen, K. and Graggen, M. N. (1996), Evaluation of Bioaccumulation Factors in Regulating Metals. Environ. Science and Technol., 30 : (10), 448A-452A.

Chiu, S. T.; Lam, F. S.; Tze, W. L.; Chau, C. W. and Ye, D. Y. (2000), Trace Metals in Mussels from Mariculture Zones, Hong Kong. Chemosphere, 41, 101-108.

CIDE (1997), Centro de Informação de Dados do Rio de Janeiro. Estado do Rio de Janeiro. Rio de Janeiro: Território. Relatório. $80 \mathrm{pp}$.

Coimbra, J. and Carraça, S. (1990), Accumulation of $\mathrm{Fe}, \mathrm{Zn}, \mathrm{Cu}$ and $\mathrm{Cd}$ during differents stages of the reproductive cycle in Mytilus edulis. Comp. Biochem. Phisiol., 95C : (2), 265-270.

De Gregori, I.; Pinochet, H.; Gras, N. and Munoz, L. (1996), Variability of cadmium, copper and zinc levels in molluscs and associated sediments from Chile. Environ. Pollut., 92 : (3), 359-368.

Förstner, U. and Wittmann, G. T. W. (1983), Metal Pollution in the Aquatic Environment. 2. ed. Springer-Verlag. 271-321 pp.

Gomes, M. P.; Carvalho, C. E. V. and Lacerda, L. D., (1991), Monitores Biológicos de Metais Pesados no Litoral do Estado do Rio de Janeiro. An. Sem. Reg. Ecol., 6, 319-329.

Kavun, V. Y.; Shulkin, V. M. and Khristforova, N. K. (2002), Metal Accumulation in Mussels of the Kuril Islands, North-West Pacific Ocean. Marine Environmental Research, 53, 219-226.

Karez, C. S.; Amado-Filho, G. M.; Moll, D. M. and Pfeiffer, W. C. (1994), Concentração de Metais em Algas Marinhas Bentônicas de Três Regiões do Estado do Rio de Janeiro. Na. Acad. Bras. Ci., 66 : (2), 205-211.

Kremiling, K. (1988), Metal Cycles in the Coastal Environments. In: Seeliger, U.; Lacerda, L. D. and Patchineelam, S. R. Metals in Coastal Environments of Latin America. Berlin Heidelberg, New York : Spring-Verlag. pp. 198-214.

Lacerda, L. D.; Lima, N. R. W.; Pfeiffer, W. C. and Fiszman, M. (1983), Size and Metal Concentration in the Mangove Mussel Mytella guyanensis (Mollusca: Bivalva) from Baía de Sepetiba, Brazil. Rev. Biol. Trop., 31 : (2), 333- 335 pp.

Lacerda, L. D.; Teixeira, V. I. and Guimarães, V. R. D. (1985), Seazonal Variation of Heavy Metals in Seaweeds from Conceição de Jacareí, Brasil. Bot. Mar., 49 : (3), 847-849.

Lacerda, L. D.; Carvalho, C. E. V.; Gomes, M. P. (1989), Nota sobre a distribuição de $\mathrm{Mn}, \mathrm{Zn}$ e Cu em siris da Baia de Sepetiba. Rev. Brasil. Biol., 49 : (3), 847-849. 
Latouche, Y. D. and Mix, M. C. (1982), The effects of depuration, size and sex on trace metal levels in Bay Mussels. Mar. Pollut. Bull., 13 : (1), 27-29 pp.

Lima, E. F. A. (1997), Determinação de cádmio, cromo, cobre e zinco em mexilhões Perna perna (LINNÉ, 1758) do litoral do estado do Rio de Janeiro. Dissertação de Mestrado. Depto de Química - PUC/RJ. 151 pp.

Machado, A. L. S. (1999), Distribuição de Metais Pesados em Macroalgas Marinhas Bentônicas no Litoral Norte do Estado do Rio de Janeiro. Monografia. Ciências Ambientais, UENF. 51 pp.

Michel, J. and Zengel, S. (1998), Monitoring of Oyster and Sediments in Acajutla, El Salvador. Mar. Pollut. Bull., 36 : (4), 256-266 pp.

Moraes, R. B. C and Silva, M. L. P. (1995), Toxicidade do zinco ao mexilhão Perna perna (Linné, 1758). Arq. Biol Tecnol., 38 : (2), 541-547 pp.

Nybakken, J. W. (1997), Marine biology: an ecological approach. $4^{\text {th }}$ ed. Addison : Wesley Educational Publishers Inc. v. 11. pp.433-440.

Páez-Osuna. P.; Frias-Espericueta, M. G. and Osuna-López, J. I. (1995), Trace metal concentrations in relation to season and gonadal maturation in the oyster Crassostrea iridescens. Mar. Environ. Res., 40 : (1), 19-31pp.

Pedrini, A. G. (1984), Algas marinhas bentônicas no litoral norte fluminense I , Lista preliminar das algas "arribadas" da praia de Manguinhos (Guaxindiba , São João da Barra, Rio de Janeiro. Atas Soc. Bot. Bras., 2 : (17), 133-141.

Pfeiffer, W. C. (1980), Trânsito do cromo em ecossistemas aquáticos. Anais. Seminário Sobre Poluição Por Metais Pesados. SEMA, Brasília Distrito Federal. 29-37 pp.

Phillips, D. J. H.; Thompson, G. B.; Gabuji, K. M. and Ho, C. T. (1982), Trace Metals of Toxicological Significance to Man in Hong-Kong Seafood. Environ. Pollut. Ser. B., 3, 27-45.

Regoli, F. and Orlando, E. (1994), Accumulation and Sub cellular Distribution of Metals $(\mathrm{Cu}, \mathrm{Fe}, \mathrm{Mn}, \mathrm{Pb}$ and $\mathrm{Zn}$ ) in the Mediterranean Mussel Mytilus galloprovincialis During a Field Transplant Experiment. Mar. Pollut. Bull., 28 : (10), 592-600.

Rezende, C. E. and Lacerda, L. D. (1986), Metais pesados em mexilhões Perna perna no litoral do estado do Rio de Janeiro. Rev. Brasil. Biol., 46, 239-247.

Rezende, C. E.; Zalmon, I. R. and Haddad, C. (1997), Metais pesados em Macroalgas Marinhas Bentônicas da Costa Norte do Estado do Rio de Janeiro. Anais. 7. Congr. Lat. Amer. Ciênc. Del Mar. 338-340 pp.

Riget, F.; Johansen, P. and Asmund, G. (1997), Uptake and release of lead and zinc by blue mussels. Experience from transplantation experiments in Greenland. Mar. Pollut. Bull., 34 : (10), 805-815 pp.
Salomão, M. S. M. B. (1997), Dinâmica do Material Particulado em Suspensão e de Metais Pesados na Porção Inferior do Rio Paraíba do Sul. Monografia. Laboratório de Ciências Ambientais, UENF, Campos dos Goytacazes, RJ.

Szefer, P. and Geldon, J. (1997), Distribution and association of trace metals in soft tissue and byssus of mollusc Perna perna from the Gulf of Aden. Yemen. Environ. Inter., 23 : (1), 53-61 pp.

Szefer, P.; Ikuta, K.; Kushiyama, S.; Szefer, K.; Frelek., K. and Geldon, J. (1997), Distribution and association of trace metals in soft tissue and byssus of Mytilus edulis from the east coast of Kyushu Island, Japan. Arch. Environ. Contam. Toxicol., 32, 184-190.

Szefer, P.; Geldon, J.; Ali, A. A.; Páez-Osuna, F.; RuizFernandes, A. C. and Galvan, S. R. G. (1998), Distribution and Association of Trace Metals in Soft Tissue and Byssus of Mitella strigata and Other Benthal Organisms From Mazatlan Harbour, Mangrove Lagoon of the Northwest Coast of Mexico. Environ. Inter., 24 : (3), 359-374 pp.

Wong, C. K. C.; Cheung, R. Y. H. and Wong, M. H. (2000), Heavy Metal Concentrations in Green-Lipped Mussels Collected from Tolo Harbour and Markets in Hong Kong and Shenzhen. Environmental Pollution., 109, 165-171.
Received: April 01, 2002; Revised: October 31, 2002; Accepted: October 06, 2003. 